Portraits and politics in classical Greece and early imperial China: an institutional approach to comparative art.

\title{
2.1.2015
}

Name: Jeremy Tanner

Address: Institute of Archaeology, University College London, 31-34 Gordon Square, London, WC1H 0PY.

Telephone: 02076791525 (w), 01223324252 (h)

Email: j.tanner@ucl.ac.uk

Biography: Jeremy Tanner is Professor of Classical and Comparative Art at the Institute of Archaeology, University College London. He has published widely in the history of classical art, the historiography of art, and the sociology of art, including his article "Michael Baxandall and the sociological interpretation of art", which won the Sage Prize for Cultural Sociology in 2011. His current research explores the transformation of the art institutions of classical Greece and early imperial China in the context of the 'Axial Age'.

This is a pre-publication text of an article to be published in February 2016 in the journal Art History, copyright Association of Art Historians and John Wiley and Sons. 


\title{
Portraits and politics in classical Greece and early imperial China: an institutional approach to comparative art.
}

\begin{abstract}
:
This article develops a comparative approach to the history of portraiture in classical Greece and early imperial China, with a particular focus on institutions of state honorific portraiture. It argues that a key role in the development of portraiture in classical Greece and early imperial China was played by the formation of differentiated political organisation in the two societies, and the need to develop new forms of reward symbolism to engage emergent elites in the project of state building entailed by the new forms of political organisation. The distinctive forms and formats of portraiture in the two traditions were shaped by the specific character of the political organisation of the two states, democratic and monarchic respectively, and by the correspondingly distinctive social values which informed elite bodily comportment in each case.
\end{abstract}

Keywords: portraits, comparative art, classical Greece, early imperial China, art and the body, physiognomics, art and politics 


\section{Portraits and politics in classical Greece and early imperial China: an institutional approach to comparative art. [2.1.2015]}

\section{Introduction: comparing Greece and China.}

Shortly after the acquisition by the British Museum in 1772 of Sir William Hamilton's collection of Greek vases, one John Elliot wrote to him as follows: 'Your collection forms one of the greatest and most admired ornaments of the Metropolis. Even foreigners come to see it. I have, with much satisfaction seen the advantageous manner in which these inestimable remains of antiquity are arranged. I really think that the national taste has received a rapid improvement from them. In place of the ponderous dull ornaments we formerly had, we now have the pleasure of seeing new embellishments daily rising up, where everything is formed in the elegant manner of the ancients. The furniture of even the houses is already changed. These improvements are totally owing to that choice collection which you have set before the public. In the most ordinary houses, in place of the unnatural, the distorted Chinese figures, we see the chimney pieces and cabinets decorated with vases equal to the Etruscans. ${ }^{\mathrm{i}}$

The contribution of Hamilton's collection to both the development of the discipline of classical art history, and the rise of classical taste in late eighteenth century England, is a well known story. Less attention has been paid, by classicists at least, to the throw away comment at the end of John Elliot's letter, remarking on the 'unnatural, the distorted Chinese figures' that classical taste displaced. Elliot's remark represents a last passing shot in a cultural debate that had lasted more than half a century. Chinese culture had been the object of growing admiration in Europe in the late seventeenth and early eighteenth centuries, and even been promoted as a possible alternative to dominant classical traditions. The non-alphabetic ideographic script of Chinese had been advocated as the basis of a perfect, universally intelligible, language. ${ }^{\text {ii }}$ The selection of government officials by examination, following Chinese practice, had been advocated by Voltaire no less as a check on the arbitrary power of monarchs and a model for 
modernising Western states. The same period saw growing imports of Chinese porcelain, and objets d'art, in the context of a craze for Chinoiserie which saw beds designed on the model of pagodas and wall-papers of Chinese figures set in exotic landscapes. ${ }^{i i i}$

In the later eighteenth century, the enthusiasm for China seems to have waned. It was replaced by Ancient Greece, which became the preferred source of political models and cultural standards. The fall of China and the rise of Greece were internally related, in the geopolitical context of the extension of European power in the Near and Far East, and in the cultural context of Romantic Philhellenism, and the orientalist attitudes which underpinned it. ${ }^{\text {iv }}$ In Germany and England, in particular, the small democratic states of ancient Greece offered an alternative political model to French absolute monarchy, and classicism an alternative to the French courtly rococo style partly fused as it was with chinoiserie. In an essay in the magazine, The World, the poet William Whitehead warned that the oriental taste threatened 'the ruin of that simplicity which distinguished the Greek and Roman arts as eternally superior to those of every other nation', telling the awful story of a certain Lady Fiddlefaddle who 'flung into the garret as lumber.. the beautiful vases, busts and statues' which her grandfather had acquired on the Grand Tour, in order 'to make room for the great-bellied Chinese pagods, red dragons and the representation of the ugliest monsters that ever, or rather never, existed'. ${ }^{\mathrm{v}}$ The second Plate of William Hogarth's Marriage à la Mode (1745) captures the prevalent attitude, showing a husband effeminised and undone - as indicated through his broken sword - by his wife's passion for things Chinese, from the expensive Chinese tea-service, to the chinoiserie fire-guard and statues of Chinese figures on the mantelpiece (Figure 1). ${ }^{\mathrm{vi}} \mathrm{We}$ might contrast Zoffany's painting of Charles Townley and his friends (painted 1781-90), enjoying his collection of classical sculptures, free of any female influences, models of the manly civic humanism which was to inform the rise of classical studies as a kind of ideological cement which served to integrate disparate fractions of the ruling class of nineteenth century Britain (Figure 2). ${ }^{\text {vii }}$

Against this cultural background, comparison with China played a key role in the formation of disciplinary paradigms in classical art history, shaping both the terms we use to describe the essential character of Greek art, and the explanatory frameworks we invoke to account for its development. According to Winckelmann, Greek art progressed from a schematic hardness, inherited from ancient Egypt, through a style of loftiness and 
grandeur to a softly beautiful style which achieved a perfect synthesis between the truth of nature and ideal reason. This progress was conditioned by, and paralleled, the progress of democracy and intellectual enlightenment characteristic of classical Greece. The art of China, by contrast, Winckelmann condemned as stagnant and unchanging; indeed the very faces of Chinese people as deviations from Hellenic and European norms he considered an inadequate model for the creation of ideal sculpture. ${ }^{\text {viii }}$ Following Winckelmann's lead, Hegel placed Chinese civilization on the bottom rung of his evolutionary ladder of world-historical development, an oriental despotism, peopled by a race incapable of 'a true political life based on the free interaction of individuals', such as characterised the Greek world and the Western tradition. ${ }^{\text {ix }}$

Winckelmann's art history still profoundly informs much of the taken for granted framework of classical art history writing, notably assumptions concerning supposedly unique characteristics of Greek art. These include naturalism and an interest in art as illusion; visual narrative in contrast to the atemporal character of the art of the ancient Near East; the separation of art from magic and ritual, and its appropriation to secular political purposes; the development of a concept of art as such, and of art critical discussion. ${ }^{\mathrm{x}}$ Ernst Gombrich's account of the development of naturalism in Greek art, for instance, is simply a modest elaboration of ideas adumbrated in Winckelmann, with a particular emphasis on the open society and critical scientific rationalism as key factors in what he calls 'The Greek revolution'. ${ }^{\text {xi }}$ Symptomatically, in his classic The Story of Art, Gombrich places early Chinese art outside history, relegating it to an eleven page chapter 'Looking Eastwards', on Islamic and Chinese art from the second to the eleventh centuries AD. ${ }^{\text {xii }}$ Yet, each of the key features claimed by Winckelmann and Gombrich as unique and defining achievements of Greek civilisation can in fact be paralleled in Han to Tang China: the appropriation of art from religious-magical frameworks into more purely political contexts in relation to portraiture, which is the primary focus of this paper; but also the relation between narrative and naturalism, and the development of art theory and criticism which there is not space to touch on here. At the very least, these parallels raise some questions about what we normally claim to be unique characteristics of Greek art, and in particular the political and cultural factors - democracy and rationality - that have been held to explain them; and as such these parallels would seem to demand more sustained comparison. 
Unfortunately, the normative paradigms established in the eighteenth century, have shaped such comparisons of Greek and Chinese art as have been undertaken in two quite problematic directions, emphasizing either the radical alterity of Chinese and Greek art, or alternatively subsuming Chinese art into the evolutionary paradigm of the history of Greek art, but as an imperfect or even derivative version. Comparisons emphasizing radical alterity tend to generalise across time the importance of the putative presence or absence of some core feature of Greek or Chinese artistic culture as explaining their characteristic differences. Norman Bryson, for example, argues that the representational traditions of Chinese and Western art 'bifurcate from the beginning'. Western painting, whether from classical antiquity or after the Renaissance informed by the concept of mimesis, supposedly absent from the Chinese tradition, employs erasive brush work, repressing deictic reference to the artist's hand, in order to effect the illusion of an unmediated access to the object of representation. Chinese painting, by contrast, grounded in traditions of calligraphy, foregrounds the presentational qualities of brushwork to establish the 'psychophysical presence of the artist' within the painting. ${ }^{\text {xii }}$

An alternative line of argument has assimilated Greek and Chinese art almost to the point of identity, sometimes even seeing many features of Chinese art as pale reflections of distant Hellenic influences. In the early twentieth century, the Austrian art historian Franz Wickhoff was perplexed by the important role played by the model of Japanese prints in the exploration of surface and flatness in late impressionist painting. ${ }^{\text {xiv }}$ How could such on the face of it discrepant traditions as oriental and western art become fused in this way, and did not these oriental influences somehow impugn the purity and integrity of the Western tradition? Wickhoff's answer to this problem was to suggest that Chinese art, and through it Japanese, was heavily influenced in its character by ancient Greek art, so that in a sense the onward transmission from Japan to France in the nineteenth century was simply Western art returning to itself. Wickhoff's examples were not particularly compelling, in part because the supposed Greek models, eyecups, turned out to be later than the Chinese art, Shang bronzes with the taotie motif, that they were supposed to have influenced. But the argument is by no means as silly as it might seem on the face of it. Recent scholarship indicates that eastward diffusion of material culture, from Western Asia to China, was an almost continuous process from the Bronze Age onwards, though with very varying levels of intensity. ${ }^{\mathrm{xv}}$ Against this background it has even been argued that the Terracotta Army of the funerary complex of the First Emperor 
emulates, at some remove, the Mausoleum of Halicarnassus, with its extraordinarily elaborate programme of sculptures. ${ }^{\mathrm{xvi}}$ A less radical version of this argument, traces the transmission of figurative sculpture through Gandhara to the Western end of the Silk Road, and sees the public sculptures of Greek communities at the far eastern extreme of the Greek world as a possible source of the idea for the Emperor's monumental figures. ${ }^{\text {xii }}$ Although there are elements of this argument which are persuasive, it is still formulated primarily in terms of stylistic influences and consequently affords little agency to the recipient Chinese culture. ${ }^{\text {xviii }}$ It does not help us, for example, to understand the distinctive character of the use of sculpture in the Tomb of the First Emperor, which turns the Mausoleum of Halicarnassus outside-in as it were: the ornament which embellishes the exterior of Mausolus' tomb being placed underground in the funerary precinct of the First Emperor, visible to the dead emperor, but not to living human beings. ${ }^{\text {xix }}$ Nor does it explain why the impact of these foreign models was so short lived: within a generation, the figures in imperial tombs had reverted to a smaller than life size scale, and to the kinds of strategies for blurring figure and prototype - for example dressing the figures in real silk dresses and equipping them with movable limbs -, which had been characteristic of such tomb figures before the First Emperor. ${ }^{\mathrm{xx}}$ That is to say, any influences are heavily refracted in terms of, and ultimately selected out by, an indigenous institution of art production.

\section{Portraits and politics}

Comparisons starting from questions of style tend to manifest an approach with what Jean Paul-Reding terms a 'norm/defect structure', that is to say the characteristics of one tradition are explained in terms of its failure to manifest the characteristics of what is essential to any art worthy of the name in the other. ${ }^{x x i}$ The Chinese tradition is said to lack both the concept of mimesis and indeed its visual concomitants such as perspective and chiaroscuro. Western art correspondingly is said to lack both an account of and an interest in the presentational character of brushwork characteristic of its Chinese counterpart. Such a starting point for comparison has two shortcomings. First, the defects prove to be more illusory than real - there is a significant interest in presentational brush work in Western art, and the idea of art as imitation is, as we shall see in due course, amply present in China, if not in the extreme form implied by Platonic metaphysics; (indeed in that latter form, of course, it was equally unavailable to Greeks before Plato, 
and shared by rather few after him). Second, approaching Chinese art in terms of what it lacks tends to tell us rather more about our expectations than about Chinese art, and vice versa when sinological art historians invoke contrasts with Western art. ${ }^{\text {xii }}$

In order to circumvent this problem, I take as my starting point the institutional contexts of art production: the social purposes for which pictures are made, and the settings within which they are consumed. ${ }^{\text {xxiii }}$ More specifically, I wish to focus in this paper on one category of art production, namely portraiture. The birth of portraiture in Greece has been seen by liberals and Marxists alike as expressing the individualism associated with democracy, and is consequently celebrated as reflecting values and institutions central to the Western way of life, a tradition of argument ultimately derived from Winckelmann. ${ }^{\text {xxiv }}$ Dietrich Seckel's account of early Chinese portraiture explicitly invokes Jacob Burckhardt's history of the Italian Renaissance in his own analysis of the Han as the period in Chinese history which marks 'the discovery of the world and man', and with it the birth of portraiture. ${ }^{\mathrm{xx}}$ But the celebratory discourse of individualism which informs both accounts is rather abruptly cut short when we come face to face with the surviving portraits. The Tyrannicides by Kritios and Nesiotes (figure 3) are held to be insufficiently realistic to count as true portraits, as also Kresilas' portrait of Perikles (figure 4): 'not a true portrait', opines John Boardman, 'any individuality reflects the artist's style rather than the subject's appearance'. ${ }^{x x v i}$ Equally historians of Chinese art feel uneasy about attributing the status of true portrait to surviving Han funerary likenesses like those from the tombs at Anping (figure 5) and Zhu Village (figure 6). Seckel, for example, describes them as 'typified images' representing 'social status' rather than 'true likenesses', representing 'individual features'. ${ }^{x v i i}$

It is clearly unhelpful to impose expectations derived from modern portraits on their early Greek and Chinese counterparts. If, as has been suggested, a portrait is less 'the faithful record of a visual experience than the faithful construction of a relational model', ${ }^{x x i i i}$ then it can be made 'to any required degree of accuracy'. ${ }^{x x i x}$ Further, if a portrait is a 'relational model', similarities and differences in the social and relational contexts of their use may help us to explain both the rise of portraiture in Han China and Classical Greece, and the distinctive visual characteristics of the two traditions of portraiture. My argument will run roughly as follows. Portraiture emerged out of the background of developing traditions of figurative art which included representations 
which could stand for particular persons, 'proto-portraits' like the archaic Greek funerary statues of Dermys and Kittylos or the Late Warring States and Early Han funerary banners. ${ }^{\mathrm{xxx}}$ In both Classical Greece, above all Athens, and Han China these developments received a decisive impulse from the use images of living and recently dead persons as a form of prestige symbolism central to the integration of the new more structurally differentiated state formations characteristic of the two periods. Portraits operated as a vehicle for articulating the relationship between increasingly centralised states, and the elites which were essential to their functioning. Portraiture offered a means of forging bonds between subjects and the state, at the expense of the competing principles of power embedded in kinship networks or brute wealth and the networks of clients built on that basis. It also, as an exemplary mode of representation, served to inculcate both the recipients of portrait honours and the viewers of portraits into commitment to the social and political values which sustained the new order.

I will analyse each case on the same set of dimensions: first: the legal and normative frameworks which regulated the use of portraits as reward symbols; second, concepts of likeness and imitation, and how they informed both the production and the reception of portraiture, in particular in terms of physiognomic theory; third, the links between these broader social and cultural contexts and the specific iconographic and stylistic features of early Greek and Chinese portraits. ${ }^{x x i}$ I will conclude by suggesting that that parallel development of an institution of honorific portraiture should be understood in terms of parallel state-building processes in classical Greece and Han China, and that the differences between the two traditions can be accounted for by the different character of the states, democratic in one case, monarchic in the other.

\subsection{Portraits and politics in classical Greece}

Let us start with the Greek case and specifically Athens, about which we are best informed. Notwithstanding modern scholars concerns about whether Greek portraits are 'true likenesses', the concept applied by the Greeks themselves to images like the Tyrannicides, namely eikon, defines them precisely as 'likenesses', and this was a

specifically new category of art developed only in the fifth century BC. ${ }^{\text {xxii }}$ There is any number of anecdotes where at least an expectation of resemblance is taken for granted. For example, one of the characters of Theophrastus, 'The Flatterer' always tells his host 
that he looks just like his portrait, implying both the notion of portraits as being defined by resemblance to their sitter, and the recognition that in fact artists were expected to improve upon the original in ways which would do him credit. ${ }^{x x i i i}$ The earliest example of an image to which the label 'eikon' is attached is the portrait group of the Tyrannicides, Harmodios and Aristogeiton. This was set up in the agora of Athens in 477/6 BC, in honour of the two friends' self-sacrifice ostensibly in slaying the tyrant who ruled Athens in the sixth century, and thus inaugurating Athenian democracy. The Athenian state seems to have been relatively conservative in setting up further portraits, although we know that the practice occurred in other communities, in particular for athletes who brought kudos to their home towns through victories in the Panhellenic games. ${ }^{\text {xxiv }}$ In the fourth century, honorific portraits become more common in Athens, and the rich documentary record allows us to reconstruct the character of the institution from surviving decrees and other testimony.

Requests for honorific portraits were made through proposals to the demos, or people, in the assembly, whether by the individual wishing to receive the honour or some representative for him. ${ }^{\mathrm{xxv}}$ The request spelled out the rationale for the honour in terms of services or benefactions that the candidate had performed on behalf of the demos and democracy. Given the great honour, or timēe, that a public portrait entailed, such claims were vigorously debated, within the assembly and the law courts, the key institutions of democratic governance. One of the descendants of the Tyrannicides challenged the award of an honorific portrait to the fourth century general Iphikrates, on the grounds that he was simply unworthy. ${ }^{\mathrm{xxxvi}}$ The orator Lykourgos brought a charge of graphe paranomon, the proposal of an illegal decree, against a certain Kephisodotos who had requested a statue for Demades, a leading orator and the primary mediator between Philip of Macedon and the Athenians in the aftermath of the battle of Chaironea. In the surviving fragments of the speech, Lykourgos pours contempt on the idea that Demades could be construed as a benefactor of the people, ironically suggesting that he should be depicted throwing away his shield, as he had allegedly in the flight from Chaironea. ${ }^{\text {xxvii }}$

As the debate over the portrait of Demades suggests, appropriate iconography was one of the issues to be discussed, whether within the assembly or a commissioning board delegated to see to the erection of the statue. Correspondingly, the iconography tied the honour embodied in the portrait to the general values or specific occasion which afforded 
the grounds for honouring the individual in question. The Tyrannicides are represented in the act of slaying the tyrant, and Chabrias's statue, standing at ease with his shield propped against his knee, recalls a stratagem adopted in a battle in which he had defeated the Spartans (figure 7a-b). ${ }^{x x v i i i}$ The iconography even of portraits which were private dedications seems to have been read against these broadly civic horizons. A painted portrait of Alkibiades, celebrating a chariot racing victory at the Nemean games, depicted him reclining in the arms of the eponymous goddess Nemea. It was condemned by the elder citizens as tyrannical and contrary to the laws, or nomoi, claiming status, as it did, on the very undemocratic basis of a special relationship to the gods. ${ }^{\mathrm{xxxix}}$

Both the iconography of portraits, and their interpretation, was informed by a physiognomic consciousness, perhaps best encapsulated in a passage of Xenophon's Memorabilia, where Sokrates, in the course of a discussion with the painter Parrhasios about the representation of ethos or character, tells us that, 'Nobility (megaloprepes) and free spirit (eleutherion), meanness (tapeinon) and servility (aneleutheron), temperance (sophronikon) and prudence (phronimon), wanton violence (hybristikon) and vulgarity (apeirokalon) are made manifest themselves through the faces of men and through the schemata or attitudes of their bodies, whether standing still or in movement' ${ }^{\mathrm{xl}}$ How does this manifest itself in practice, in relation to the kind of bodily schemata characteristic of the Tyrannicides, or of generals like Perikles and Chabrias for whom we can use the bronze statuette from Hartford (figure 8), and the stele of Lykeas and Chairedemos (figure 9) as proxies, in the light of the fact that our Roman copies of these portraits preserve only their heads. In Athens and other Greek poleis, young citizen men were inculcated into a specific relationship to their own bodies during the ephebeia, a period of military and civic training which marked the transition from adolescent to adult citizen. This training culminated in public beauty competitions in which teams, organised on the basis of the tribes into which the citizen body was divided, vied for prizes for euandria, good manliness, euexia, fineness of physical disposition, and eutaxia, good orderliness. ${ }^{\text {xli }}$ In our images, the combination of muscular tension, restricted movement and balanced contrapposto characteristic of the stele from Salamis and the Hartford general embody an ethos of kosmiotes or orderliness, characteristic of the man who is courageous and trained in temperance or sophrosyne. ${ }^{x l i i}$ The composition of the limbs of the more active Tyrannicides, and their sinewy musculature, recall Plato's description of another ephebic exercise the pyrrhic dance, a preparation for war. This involved, in Plato's words, the 
acting out of 'the movements which result in aggressive postures (schemata)...[] imitations of the delivery of every kind of blow': in the dance 'the body [is] kept erect (orthon), in a state of vigorous tension (eutonon), with the limbs extended nearly straight (euthupheres)', displaying the 'fine physique' which indicates the noble soul and courageous character of those prepared to 'use their bodies in service of the city' on behalf of democratic freedom. xliii $^{\text {. }}$

This sensitivity to bodily comportment, and the evaluative vocabulary associated with it, extended into the practices of everyday life, as a form of symbolic capital indicative of an individual's internalisation of democratic civic values. Fast walking and a broad gait were associated with aristocratic arrogance, the opposite of the kosmiotes and sophrosyne which was the ideal of the democratic citizen. In a speech from a fourth century trial, one litigant tries to explain away his 'fast walking' as congenital defect which he could not control and should not be held responsible for, not, as his opponents had suggested, a sign of bad character. Another counters criticism of his loud voice and fast walk by noting that in fact his actual style of life was 'more measured' (metrios) and 'well ordered' (eutaktoteron) that that of his opponent in the case at hand. ${ }^{\text {xliv }}$ Perikles in particular seems to have been regarded as an exemplar of the deportment appropriate to democratic leadership. As described in Plutarch's life, in public space he manifested 'a composure of countenance that never broke down into laughter, a gentleness in his movements, a dignity in the arrangement of his attire subject to no disturbance by any emotion in speaking'. ${ }^{x}$ This ideal of praotes, gentleness, remained current into the fourth century, and it is presumably this which is manifest in the fourth century portraits of generals like Konon and Chabrias modelling themselves on the precedent of Perikles. Other looks were also valued, particularly in association with the kinds of intellectual attributes which were increasingly desired of Athenian politicians, whether in their capacities as orators, or ambassadors, or in the context of the increasingly complex financial management of the state, ${ }^{x l v i}$ all roles which required the kind of text-based education associated with the Sophistic movement. A speech by an unknown sophist in the corpus of Isokrates instructs a young man about to enter into public life 'to habituate yourself not to appear gloomy (skythropon) in your countenance, but thoughtful (sunnoun); for the former will make you seem self-willed, while on the basis of the latter you will be judged intelligent (phronimos) ${ }^{\text {, }}{ }^{x l v i i}$ What counted as appearing phronimos seems to have varied according to age, and the more markedly knit-brows of the 
skythropos are referred to approvingly in descriptions of the "venerable face[s] of the members of the Areopagus', the council of former archons or chief magistrates of Athens. ${ }^{\text {xlviii }}$ The mid fourth century portrait of Plato (figure 10) differs from contemporary representations of male citizens in funerary stelai only by a heightened emphasis on brow contraction, making a claim to civic esteem for the phronimos, the individual capable of managing civic affairs well by virtue of his powers of practical reasoning. ${ }^{\text {xlix }}$

Portraits like those of Plato, set up on the private initiative of one of his pupils, made a claim to public esteem in terms of shared civic values. Public honorific portraits were set up to encourage emulation of model behaviour on the part of political elites eager themselves for such honours - and of the citizenry at large. Long after his death, a portrait of Sokrates (figure 11a-b), by Lysippos, was set up in the Pompeion, a large hall at one of the gateways to the city, which functioned, amongst other purposes, as a place of assembly for the ephebes. His thoughtful visage manifests the ideal of the phronimos, and he embodies kosmiotes in his pose, with both hands clasping the overfolds of his drapery, to ensure it will maintain its ordered disposition even when he moves. ${ }^{1}$

Something of the cultural logic which informed these emulative expectations can be gleaned from a debate over a portrait of the sixth century law-giver Solon, set up on the island of Salamis. In his prosecution of Timarchos, an associate of Demosthenes, on a charge of homosexual self-prostitution, the orator Aiskhines invoked a portrait of Solon, with his arm wrapped inside his mantel as an emblem of sophrosune, civic propriety, presumably something similar to the famous Lycurgan portrait of Sophokles (figure 12) or indeed a somewhat later, possibly posthumous, statue of Aiskhines himself (figure 13). Aiskhines invokes the statue in order to draw to contrast with the behaviour of Timarchos, who, he claims 'at a meeting of the popular assembly, tore off his cloak and leapt around half-naked, like some all in wrestler, his body in such a foul and disgraceful condition, the consequence of drunkenness and debauchery, that right minded men at least veiled their faces, feeling ashamed on behalf of the city, that we should make use of such men as this as our advisors'. ${ }^{l i}$ In his speech in defence of Timarchos, Demosthenes describes how Aiskhines as he spoke about the statue of Solon as the proper model of conduct, seems to have taken on its posture. He imitated (emimesato) its' schema, as Demosthenes put it, thus assimilating himself to the character of the exemplary statesman of the past, a 
paradeigma sophrosynes, at least as he would have the audience of jurors believe. This implicit claim Demosthenes in his turn goes to some effort to demolish. First he points out that the statue of Solon must have been made hundreds of years after that statesman's death, and so could not tell us anything about the political deportment of his age. Second, Demosthenes begins to open up the gap between representation and reality implicit in the concept of an eikon, suggesting that it would have been better for Aiskhines to have imitated not the mere appearance of Solon, the schema, but his spirit and purpose, psyche and dianoia. ${ }^{\text {lii }}$

On the one hand then, portraits were a central element in a mimetic culture of civic emulation: their language, and their material presence in civic space, afforded a medium through which political values were articulated, and inculcated, an ever present measure of standards of propriety, and of dedication to the state, to which citizens might be held. On the other hand, hovering on the edges of the assumptions that informed this institution, there was also a potential contradiction, an ambivalence about this order of images, eikones, being nothing more than imitations of appearance, and as such a weak foundation for the social order which they ostensibly upheld. This cultural contradiction was of course opened up and explored rather systematically by Plato in Republic Book 10, but it already informed the somewhat dismissive attitude to portraiture of poets like Pindar and orators like Isokrates, sceptical of the capacity of portraits authentically to transmit memory or incarnate values with the same living force as the arts of the word. ${ }^{\text {liii }}$ Similar concerns about visual imitation and authenticity were also raised in relation to portraiture in China.

\subsection{Portraits and politics in early imperial China}

The vocabulary used in early imperial China in describing what we translate as portraits is more diverse than that of classical Greece, and there is no sudden marked conceptual innovation equivalent to the emergence of the concept eikon. In the Han histories, when the emperor commissioned a series of portraits of distinguished officials, we are told he 'tuhua qi ren 圖畫其人 - had their persons depicted in painting' and 'fa qi xingmao 法其形貌 - modelled their bodily form and appearance'. liv By the later Han, however, the most common terms used to described portraits are the homophones 象 
(image, figuration) and 像 (xiang). ${ }^{\text {lv }}$ The latter term combines the graphs for image and person, so 'image of a person' or 'likeness'. And, as in the ancient Greek case, there are a number of contemporary anecdotes which indicate an expectation that the portrait should look like its sitter. When the emperor wants to know what a recluse who refuses summons to court looks like, he sends his painters out to make a portrait of him. ${ }^{\text {lvi }}$ One interesting story tells of the circumstances under which the beautiful and honest Wang Qiang, one of the imperial concubines, was married off to the chief of the Xiong-nu barbarians. The emperor had so many concubines that he was accustomed to select his companion for the evening by looking through a collection of portraits. Almost all the concubines, eager for imperial favour, had bribed the palace painters to depict them more beautiful than they really were, except honest Wang Qiang who was correspondingly painted less good looking than was in fact the case by the disgruntled painter. When the Xiong-nu chief, on a visit to the imperial court, asked for a Han wife, the emperor looked through his collection of portraits, and selected Wang Qiang as the least beautiful and hence most dispensable. When Wang Qiang was brought to the Xiong-nu chief to be handed over, the emperor was stunned by her beauty and manifest good character. It was too late to reverse his decision, but he did punish the five palace painters responsible for the portraits, all of them being executed along with their families. lvii

As in the Greek world, the most socially salient use of portraiture seems to have been honorific, a form of prestige or reward symbolism designed to celebrate distinguished service to the emperor and the state, or guo, by great men of the present, recent and sometimes not so recent past. The History of the Former Han describes, how, in $51 \mathrm{BC}$, the emperor Xuan, possibly in the context of preparations to receive a visit from the king of the Hun, coming to submit himself at the court,

remember[ed] with admiration the great men who had acted as arms and legs to their sovereign, had portraits of them painted (tuhua qi ren 圖畫其人) in the Unicorn Hall. A likeness was made of each man (fa qi xingmao 法其形貌), identified with his office, fief, family name and personal name; only in the case of Huo Guang was the personal name omitted. These are the names: General of the guard, marquis of Fu-ping, Zhang An-shih; [] Grand Tutor to the Heir Apparent Xiao Wang-zhi etc... All were men of merit (gong 功) and virtue (de 德) whose names were known to the world of their time (知名當世), and in this way they 
were held up as examples (以表而揚之), and given further recognition in bringing about a renaissance of the state.... ${ }^{\text {viii }}$

The Unicorn Hall was named after a painting of a unicorn that had supposedly been seen in the kingdom, a traditional auspicious omen, indicating the heavens' favourable disposition towards the emperor, and the exemplary character of his rulership. ${ }^{\text {lix }}$ The persons in question seem to have been listed, and portrayed, according to the level of their service to the state, not least their role in placing Xuan himself on the throne. They included persons both living, and recently dead. The omission of the name of Huo Guang seems to have been a special honour, analogous to the emperor not addressing men of exceptional spiritual power by their personal name, since this would imply a hierarchical relation. ${ }^{1 \mathrm{x}}$ Something of the honour that these portraits entailed may be gathered from the comment of the later Han intellectual Wang Chong. In an essay on 'The Neccessity of Eulogies' (xusong 需頌), to which we will return later, he comments, 'During the time of the emperor Xuan, captioned portraits of the distinguished officials of the Han were painted. The sons and grandsons of those who were not represented amongst the paintings were ashamed. Why is this? Their fathers and grandfathers were not worthy; so their portraits were not painted' lxi

In $60 \mathrm{AD}$ the Later Han Emperor Ming commissioned a similar series of portraits to decorate the Cloud Terrace (Yuntai) in the Southern Palace of the capital city Luoyang. It included portraits of some twenty eight generals and statesmen, notable amongst them those who helped his father the emperor Guangwu secure the throne after the Wang Mang interregnum. ${ }^{\text {xii }} \mathrm{A}$ eulogy by Ban $\mathrm{Gu}$ accompanied the portraits, celebrating the officials and the emperor they had served: 'In pursuing his imperial career/The emperor longed for meritorious [assistants]./ These men, arising from different regions,/ Helped him complete the great undertaking./ The emperor was like a dragon flying in the sky, /And accompanying him were the great statesmen'. 'xiii In addition to such memorial halls, portraits also seem to have been painted in the main audience halls of the imperial palaces. In $177 \mathrm{AD}$, the emperor Ling had portraits of a recently retired chief minister and a renowned general painted in this location, with a eulogy by Cai Yong: 'Like great mountains, dignified,/ They assisted and accompanied [the Son of] Heaven". ${ }^{x i v}$ Read alongside the placement of the portraits surrounding the emperor in a chamber in which he gave audiences to officials or received foreign rulers, these eulogies suggest that in 
addition to functioning as honours for those portrayed, such portraits of officials also demonstrated the emperor's worthiness as ruler through the worthiness of the officials he appointed and rewarded.

The exact circumstances and protocol which determined who received a portrait and why are not as transparent as in the Greek case with its clear democratic procedures. The decision must ultimately have been in the hands of the emperor, in consultation with his advisers. One occasion on which the politicking which must always have informed such decisions does become very visible is the creation of a series of portraits for the newly established Hongdu Academy. This institution was founded in $178 \mathrm{AD}$ at the instigation of some of the inner palace circle, and especially the eunuchs, who surrounded the person of the emperor. Its specific purpose was to offer an alternative context for training in government service to that of the long-established Imperial Academy, dominated by the Ru, classical Confucian scholars. The plans for the Hongdu Academy included a series of portraits and eulogies of its cultural exemplars, including its eunuch proponents Jiang Lan and Le Song. Yang Qiu, the Director of the Imperial Secretariat wrote a memorial to the throne in protest:

There has been an edict ordering palace artisans to make portraits and eulogies (圖像立贊) of thirty-two men for the Hongdu Academy, including [the eunuchs] Le Song and Jiang Lan. Now I have heard from Master Zuo's Commentary that 'whatsoever the ruler raises up must be recorded'. If those recorded are not displayed as models (書而不法), then future generations have no way of contemplating on them (和觀). Now Song, Lan and the others are cheap, common types who get into power by family relations... Some donate a [fancy] prose poem or some [stylish] bird-calligraphy and thus are raised to the status of gentleman of the court and have their portraits painted... Your humble servant has heard that portraits are made to encourage good morals and to discourage bad morals, so that the emperor can clearly see the strong and weak points of his people. But I have never heard that cheap knaves who fake their work could steal the glory in this way and have their portraits painted. ${ }^{1 \times v}$

Notwithstanding these protests, the cycle of portraits in the Hongdu Academy seems to have gone ahead, although subsequently portraits of Confucius and his seventy two disciples were also painted on the walls of the Academy, to encourage the students, and 
perhaps to mollify the Confucian classicists. ${ }^{\text {lxvi }}$ Exactly how these decisions were reached is not revealed, but on another occasion, when the emperor Ming had been asked why one General Ma, an extremely successful general who had fallen from favour, was not included in the line-up at the Cloud Pavilion, we are told 'the emperor laughed, and said nothing' - and that was the end of discussion. ${ }^{\text {lxvii }}$

What did these portraits look like? The short answer is that we do not know, since neither copies, nor even fragments, of original examples survive. There are, however, a series of Eastern Han and later tomb paintings which there is some reason to believe give us quite a good idea of the general effect that the historically attested portrait paintings may have given, if not of their artistic quality.

The so-called tomb of Bin Wang from near Xunyi, Shaanxi Province dates to the late second century $\mathrm{AD}$. A complex program of funerary iconography culminates in the sarcophagus chamber. Here, flanking the sarcophagus most probably of General Guo (not Bin Wang) and his wife we encounter a series of portraits (figures 14a-b). On one side General Guo and an assistant are approached by a series of officials, each with his name and official position painted beside him, reminiscent of the series of portraits of officials set up by emperor Xuan in the Unicorn Hall: Mr Wang, Mr Zhang and Mr Zhu, officials responsible for public security, are followed by what appears to be a self-portrait of the painter, huashigong 畫師工-, though his name, sadly for us but perhaps in some ways fortunately for him, does not survive. On the opposite wall were painted General Guo's wife and children, and the wives of the aforementioned officials, including the painter. $^{1 \text { xviii }}$

A similar concept is to be found in a tomb at Wangdu, in Hebei, also of late second century date (figures 15a-b). ${ }^{\text {lxix }}$ The west and east walls of the front chamber are decorated with a series of figures of officials looking north towards the tomb chamber of their patron, the Marquis of Fuyang, some kind of local governor, who is celebrated in a eulogy of the four character phrase type painted in the corridor between the front chamber and the western side chamber. Each figure holds a $h u$, or tablet of office, in his hands, bending at the waist in a gesture of respect towards the deceased. Underneath the figures, are depicted a series of animals of good omen, again reminiscent of the 
decoration of the Unicorn Hall, named after a painting of the eponymous auspicious beast and with its cycle of portraits of officials commissioned by emperor Xuan. All of the figures are inscribed with the titles of their office: the Officer of the Bureau of Criminals, the Benevolent and Merciful Senior Clerk, The Achievement Officer, the Circuit Officer and so on. But none of them are named as in the Bin Wang/General Guo Tomb and we should probably think of them as generic servants in eternity for the Marquis of Fuyang, analogous to the figures of the Terracotta army in the Tomb of the First Emperor. That said, the Wangdu Tomb perhaps gives us some idea of the appearance of the approximately contemporary audience hall of emperor Ling, with its cycle of portraits of officials, and a similar eulogy. Like the emperor, the Marquis of Fuyang is represented through the portraits of his exemplary officials.

The Anping tomb is another vast chamber tomb from Hebei Province, possibly built by one Zhao Zhong, a member of the local office holding class, for himself and his mother. ${ }^{\mathrm{lxx}}$ In the interior, having passed some guardian figures, visitors to the tomb encounter in the first side chamber a group of officials in animated conversation. They are led on from these through a passage way by a further series of figures of officials, in each case holding the tablet of office and inclined at the waist in a gesture of respect towards the portrait of the deceased who dominates the south wall of the second side chamber, more than life size in scale at six feet even seated (figures 5 and 16a-b). His bulky figure is raised on a dais, backed by a screen, protected by some kind of canopy, and flanked by serving figures to his right. His right hand is raised, holding what may be some kind of fan, or face covering device; his left hand rests on his waist. He is dressed in a crimson robe, with black and white edging; and wears a conical hat. His face is treated with particular care, the energetic and springy brush-line of his eyebrows, the moustache and luxuriant whiskers serving, according to one recent account, 'to transform a generic seated figure type into a specific individual'. ${ }^{\text {xxi }}$ The basic concept of these pictorial programmes, showing the deceased as an official being offered respect by his subordinates continues to be popular in northern China in the period after the Han at least until the fourth century AD, as exemplified by, for example, the Tokhungri Tomb, in what is now Northern Korea, dated to 408 AD. ${ }^{\text {lxxii }}$

On the basis of the texts from the dynastic histories, and taking these images as proxies for the portraits discussed therein, what can we say of the significance of the style 
and iconography of these images, and the way in which they may have been responded to by their viewers? As in classical Greece, so in early imperial China there was an intense physiognomical awareness which informed the reading of persons' bodily comportment and facial expression as indices of character, in particular of their suitability for government service. This culminated in texts like Liu Shao's Renwuzhi, 'The Study of Human Abilities', written shortly after the fall of the Han, in which the author systematically classifies the different characters of men in terms of their suitability for specific offices, by means of the interpretation of exterior bodily signs. ${ }^{\text {lxxiii }}$ These signs were read as manifestations of the interior balance in an individual's inner organs between the five elements (wood, metal, fire, earth and water), and the corresponding virtues of benevolence, righteousness, propriety, wisdom and trustworthiness. ${ }^{\text {lxiv }} \mathrm{A}$ growing interest in character judgement, and a corresponding concern with correct deportment, seems to be a characteristic feature of the Han, concomitant with the development of the state bureaucracy, and the role of a system of recommendations for office, based on reports of good character. ${ }^{\mathrm{lxxv}}$ Of particular interest for our purposes is an essay by the broadly Confucian Eastern Han thinker and essayist Xu Gan. ${ }^{1 x x v i}$ In an essay entitled faxiang - 法象, 'Establishing Models and Exemplars', he describes how the gentleman, the junzi, should through his bodily comportment establish himself as an exemplar for others:

It is by establishing models and exemplars that the gentleman is made (夫法象立, 所以為君子). Of the various models and exemplars none is more primary than preserving an upright countenance (正容貌) and taking care to maintain an aweinspiring demeanour (愼威儀).... The countenance is the external side of one's tally. The external side of one's tally being rectified, therefore one's emotional responses and spontaneous tendencies will be properly ordered (情性治). One’s emotional responses and spontaneous tendencies being in proper order, therefore, humaneness and rightness will be maintained (仁義存). Humaneness and rightness being maintained, therefore, replete virtue is manifest (盛德著). When replete virtue is manifest, one can be a model and exemplar (法象). ${ }^{1 x x v i i}$

The concepts $f a$ (法) and xiang (象) are of course closely related to those associated with portraiture. Xiang is one of the graphs in the character for portrait (像), likewise 
pronounced xiang, and the term $f a$ is also used in the texts from the dynastic histories we have looked at to describe the making or modelling of a portrait.

Appropriate comportment varied from context to context, and the true gentleman was as adept at showing appropriate deference in court as radiating replete virtue within his own household:

Thus, when standing in court, one should incline oneself respectfully, and when saluting one should hold one's arms as though embracing a drum. When turning around, one should make a full about turn, and when turning to either side, one should do so at a right angle. When speaking to one's superior, one's gaze should remain within the area of his waist sash and collar, and one's speech should not exceed the boundary of what has been marked out and determined. Thereby, the force of one's words will become a model; one's spirit will become an object of fond admiration （精神可愛）; one's physical movements [lit: looking down/bowing and looking up in reverence] will become an object of veneration (俯仰可宗); and one's deference will become praiseworthy ( 揖讓可貴). ${ }^{1 x x v i i i}$

The figurative language of the portraits in our tombs seems to fit nicely within the interpretive horizon suggested by these texts. The praiseworthy deference of the junior officials suggests their self-cultivation as moral and political exemplars, as well as that of their tomb-masters, whose manifestation of replete virtue, most strikingly embodied in the Anping portrait, occasions the proper deference of the junior officials.

Courteous deference (rang 讓) was held to originate in filial piety (xiao 孝), and both these values were explicitly promoted by the Han state, most notably in the Classic of Filial Piety, a text attributed to various early Confucian worthies, but probably only concocted in the middle Western Han. ${ }^{\text {lxix }}$ This text aligned filial piety in family contexts with loyalty to the state, since the deference or subordination taught within the family could be transferred to one's superiors in the official bureaucracy, all the way up to the emperor who was both mother and father to the people. Consequently, filial piety became one of the key criteria used in recommendation for bureaucratic office. In the Eastern Han, the dowager Empress Deng encouraged regional officials to offer lectures on the Classic, and the palace guards were required to memorise it. ${ }^{1 \mathrm{xxx}}$ It is perhaps not a coincidence that another striking feature of the Anping tomb, rather seldom commented on, is a series of 
inscriptions painted onto the bricks of the vaulted ceilings of several chambers, taken from the Classic of Filial Piety and Confucius' Analects. The Northern Chamber, for example, contains, amongst others, twenty six repetitions of the phrase: 'Those who love their parents do not dare to hate others', and thirteen repetitions of 'Yen Ping Chang excelled in friendship; even after long acquaintance he treated his friends with reverence'. ${ }^{\text {lxxi }}$ We should perhaps imagine the deceased, Zhao Zhong, as following the recommendations of the third-century BC philosopher Xunzi, who encouraged the noble man to intone the phrases of the Classics 'over and over again, to make them penetrate his whole being'. Ixxxii When the gentleman holds fast to these values, this will be manifested in his body as 'resplendent virtue' (de zao, 德藻), by means of which he becomes a model willingly emulated by others who seek to transform themselves in his likeness.

The value of filial piety thus informed relations of super- and sub-ordination from the family, through local government offices, all the way up the relationships between senior officials and the emperor at the summit of the hierarchy of the state, in a kind of fractal relationship whereby the relationships of filial piety at the top, encompassed and guaranteed their replications throughout the empire. Correspondingly, we might see the sets of tomb portraits as mid-level fractal replications of their counterparts in the imperial palaces, which had a homologous programme and character, and, one might infer, probably looked rather similar to their counterparts in the tombs, which may even have been painted in emulation of them.

As in classical Greece, portraits seem to have become a significant means of articulating and inculcating core values which informed the developing imperial state, as part of a broader culture of the imitation or emulation of exemplary figures; but there were also, around the edges of the institution, moments of questioning, and doubt, about the gap between visual imitations and the desired object of imitation, and about the relative value of words and images as mediators of social values. One example occurs in a text on debates about the state monopolies on salt and iron production, argued between modernising legalists and a group described as wenxue, literati, of a more traditionally Confucian orientation, insistent on the role of morality in government. In one passage, the legalists attack their opponents as follows: 
Confounders of truth (亂真) you are, with your flinty faces and mushy hearts; you confound reality (亂實) with your cultured appearance and plebeian insides （文 表而枲裏 wenbiaoerxili -hemp!). You plagiarise (糃 qie; lit: steal) the Duke of Zhou in your dress（䩹周公之服） with all those well cuffed robes and loose belts, plagiarize Confucius in your appearance（䑪仲尼之容） with all those low crooked curtsies and mincing steps. ${ }^{\text {lxxiii }}$

Confucius and the Duke of Zhou represent the moral integrity of days of old, and in imitating their styles of dress and movement, as described in classic texts and represented in the programmes of portraits of loyal ministers and the like, the literati were claiming to embody authoritative classical values, a claim which their opponents seek to undo, opening up the gap between the behavioural signifier and the values and moral authority it sought to signify, in much the same was as Demosthenes did in relation to Aiskhines' imitation of the statue of Solon. The gap between visual imitations and what they claimed to represent was also problematized in relation to more long standing media for the allocation of social prestige, namely texts and particularly texts inscribed on bronze. In his Balanced Discourses, the retired official Wang Chong comments critically on the current uses of painted portraits. 'Would it not be better to be informed of the doings and sayings of these men than to look at (jian) their faces? Painted on a bare wall their shapes and figures are there, but they do not act as incentives, because people do not see (or contemplate - guan) their words and deeds. The sentiments left by the sages shine forth from bamboos and silks, where they are written, which means much more than paintings on walls'. lxxxiv

\section{Conclusions: the state, political organization and the development of portraiture} in classical Greece and early imperial China

It seems clear from these comparisons that there are a number of striking parallelisms between the histories of portraiture in classical Greece and early imperial China, in particular in the role played by an institution of state honorific portraiture. What does that entail for how we should understand and explain the rise of portraiture in classical Greece and early imperial China? Democracy was clearly important to the character of the institution of portraiture in Greece, at least in classical Athens, as was the monarchic character of government in the Chinese case. But the very fact that the 
development of a monarchic state in China gives rise to a parallel institution of portraiture to that characteristic of classical Athens suggests that democracy per se, and the associated rise of the individual, is perhaps not a compelling explanation for the development of portraiture. It would perhaps be more persuasive to see the Greek case and the Chinese case as two different specifications of parallel processes of structural transformation, mediated by differing political organization, democratic in the one case, monarchic in the other. This entails looking outwards to broader macrostructural features of the societies in question, and transformations in them against the background of which these institutions of portraiture developed.

Limitations of space permit only the barest sketch, though the general idea may be implicit in the institutional analysis already presented. The societies of classical Greece and early imperial China represent the long term culmination of parallel processes of structural differentiation, during the Archaic and Warring States periods respectively. Key features of these processes involved increasing displacement of bronze by iron for tools, and with it the emergence of an increasingly autonomous and productive peasantry; increased urbanization, with craft production oriented towards the market, and the use of coined money as a medium of exchange and the storage of value. ${ }^{\text {xxxv }}$ All these changes freed up resources, including new kinds of cultural elites, which were made use of by political actors in creating increasingly centralised states, with differentiated political institutions: Kleisthenes in Athens, Qin Shi Huangdi, the first emperor, and his Han successors in China. In both cases, the creation of the new differentiated political order entailed the curtailment of alternative focuses of political organization, particularly those which embedded power in competing lineages, which cut against the centralization of state power and the creation of differentiated political institutions.

The development of portraiture as a form of reward symbolism played into these broader social transformations, serving a role in enhancing the affiliation of emergent elites with newly crystallising state formations. In both cases portraiture seems to have displaced other kinds of art objects that had functioned in a different way, and which had constructed elite status in terms of privileged access to the sacred or brute wealth, the two sometimes fused. In the Greek case portraits, whether as political monuments or dedications in sanctuaries, displace the traditional kouroi and korai which had assimilated an aristocratic elite to the gods and played a central role in the construction of prestige for 
kin groups in the context of funerary ceremonies at family burial grounds. ${ }^{\text {lxxvi }}$ In the Chinese case, the rise of portraiture is roughly contemporaneous with the final disappearance of ritual bronzes. ${ }^{\text {lxxxvii }}$ Such bronzes had also been, in part, symbols of political integration, in so far as at least some of them celebrated gifts to particular individuals from the Zhou kings who were the nominal rulers of China. But they were symbols of a state which was integrated by means of the dispersal of power and authority to highly autonomous lineages, whose leading men were effectively independent rulers of the cities where they held sway. The bronzes were embellished with inscriptions which celebrated the longevity of these lineages, and they were used in exclusive clan rituals in ancestral temples, designed to ensure the propagation of the lineage through proper cultivation of the ancestors. Wu Hung has traced the increasing displacement of both bronzes, lineage temples and the rituals associated with them, during the course of the Warring States, and the increasing importance of palaces as centres of specifically political power focussed on a single individual, first the several rulers of each Warring State, ultimately the emperors of a unified China, first under Qin, then under Han. ${ }^{\text {lxxxviii }}$ The dynamic tension between centripetal and centrifugal forces in the structuring of the Chinese state continued to play itself out under the Han, and development of an institution of honorific portraiture should be seen in this context. ${ }^{\text {lxxix }}$ It introduced a new paramount status symbol, which rewarded elite participation in the life of the state in a way analogous to the earlier bronzes, but on a fundamentally new basis, in so far as it celebrated the persons represented in specifically political terms, their achievements on behalf of the state, not in terms of special religious status, personal wealth or aristocratic descent, which could be an independent basis of power.

A comparative approach enriches our understanding portraiture in classical Greece and early imperial China, and offers a sharper framework for explaining the development of portraiture and its specific characteristics in each tradition. In particular it facilitates the delineation of the interactions between social structure, political organisation and cultural values as the generative matrix within which portraiture developed. As such, a comparative institutional approach cuts against the tendency towards reductionism of some approaches in the social history and sociology of art. Far from being a simple epiphenomenon of a particular kind of differentiated state organisation, honorific portraiture in classical Greece and early imperial China was, as we have seen, a significant arena of social competition and a major medium for political 
integration. It was also, as an entailment of that function, a focus for certain kinds of social and cultural tensions or conflicts: conflicts over the terms according to which various forms of symbolic capital were to be transformed into prestige within the new political order; and tensions between different media, visual and verbal, as the cultural instruments for the articulation and materialisation of status. A full analysis of all these media and materials would be needed for a complete understanding of exactly how institutions of portraiture crystallised in classical Greece and in early China, doubtless with significant differences in the former case between radical democracies like Athens, and cities with other, less inclusive, polities, but that awaits further research.

Jeremy Tanner

Institute of Archaeology

University College London

Acknowledgements: Versions of this paper were given in Cambridge and London, and I grateful to the audiences on these occasions for questions and comments which have improved my arguments. Jas Elsner Geoffrey Lloyd, Michael Squire, Jenny So and Roel Sterckx kindly read the complete manuscript and offered detailed criticism; I am grateful to all of them, as also to the two anonymous readers for Art History, for their very helpful suggestions. 
${ }^{\mathrm{i}}$ Ian Jenkins and Kim Sloan, Vases and Volcanoes: Sir William Hamilton and His Collection, London, 1996, 60-1.

ii David Porter, 'Chinoiserie and the aesthetics of illegitimacy', Studies in Eighteenth Century Culture , 28, 1999, 27-8.

iii Porter 'Chinoiserie', 27-8

iv Gregory Blue, 'China and Western social thought in the modern period', in Timothy Brooke and Gregory Blue eds. China and Historical Capitalism: Genealogies of Sinological Knowledge, Cambridge, 1999, 57-109. H.-F. Hung, 'Orientalist knowledge and social theories: China and European conceptions of East West differences from 1600 to 1900', Sociological Theory 21.3, 2003, 245-80. Jeremy Tanner, 'Ancient Greece, early China: Sino-Hellenic studies and comparative approaches to the classical world', Journal of Hellenic Studies 129, 2009, 105. Martin Bernal, Black Athena. The Afroasiatic Roots of Classical Civilization. Volume 1: The Fabrication of Ancient Greece 1785-1985, London, 1987, 172, 190, 237-40.

' Porter 'Chinoiserie', 40.

${ }^{\text {vi }}$ For the strongly (female) gendered associations of Chinoiserie in late eighteenth century England, see Dawn Jacobson, Chinoiserie, London, 1993, 130-9: for example: 132, Chippendale advertising Chinese styled chairs as 'very proper for a Lady's dressing room'; 124-5 for the complex, changing and often contradictory associations between anti-French feeling and attitudes to rococo, and classicism and English patriotism.

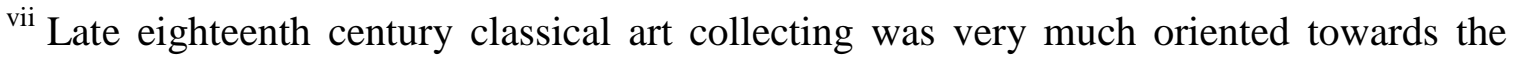
public sphere, as implied by the emphasis on 'the public' and 'national taste' in Eliot's comments on Hamilton's collection quoted above. It was informed by the same discourse of civic humanism which inspired the establishment of institutions such as the Society of the Arts, the Society of Antiquaries and so on, all institutions of an exclusively masculine public sphere: Jenkins and Sloan, Vases and Volcanoes, 76-8.

${ }^{\text {viii }}$ Blue 'China and Western social thought', 70, note 53. J.J. Winckelmann, History of the Art of Antiquity, translated Harry F. Musgrave, Malibu, 2006 [1764], 194 on slanting eyes and flattened nose of Chinese as 'a deviation from the norm'.

ix Blue, 'China and Western social thought', 92.

x Philippe Bruneau, 'Situation méthodologique de l'histoire de l'art', Antiquité Classique 44, 1975, 457-62. 
${ }^{\mathrm{xi}}$ Ernst Gombrich, Art and Illusion: a Study in the Psychology of Pictorial Representation, London, 1960, Chapter 4 'Reflections on the Greek Revolution'.

xii Ernst Gombrich, The Story of Art, London, 1984. The implication seems to be that there was no art in China before the second century AD. Compare the two chapters on Greece, twenty pages on 'The Great Awakening' and fourteen pages on 'The realm of Beauty'.

xiii Norman Bryson, Vision and Painting: the Logic of the Gaze, London, 1989, 89 ('bifurcate from the beginning'), with the discussion of Wen C. Fong, 'Prologue: Chinese calligraphy as presenting the self', in Ouyang Zhongshi and Wen C. Fong eds. Chinese Calligraphy. New Haven, 2008, 1-31, esp. 5 on 'the psychophysical presence of the artist'.

${ }^{\text {xiv }}$ Franz Wickhoff, 'On the historical unity and the universal evolution of art', in G. Schiff ed. German Essays in Art History, New York, 1988 [o.v. 1900], 165-172.

${ }^{\mathrm{xv}}$ Jessica Rawson, 'The Eternal Palaces of the Western Han: a new view of the universe', Artibus Asiae 59 (1/2), 1999, 5-58.

${ }^{x v i}$ Richard Barnhart, 'Alexander in China? Questions for Chinese archaeology', in X. Yang, ed New Perspectives on China's Past. Chinese Archaeology in the Twentieth Century, New Haven, 2004, 329-43.

xvii Lukas Nickel, 'Tonkrieger auf der Seidenstrasse? Die Plastiken des ersten Kaisers von China und die hellenistische Skulpturen Zentralasiens', Zurich Studies in the History of Art/Georges Bloch Annual, 13/14, 2006/7 (published 2009), 124-49. Lukas Nickel, 'The First Emperor and sculpture in China', Bulletin of the School of Oriental and African Studies 76.3, 2013, 413-447.

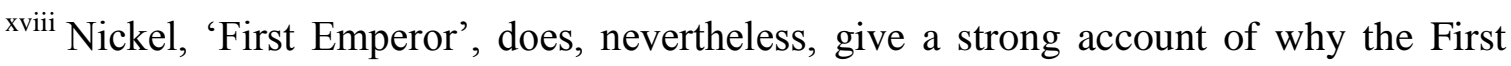
Emperor was interested in the 'Far West', in terms of articulating the scope of his terrestrial empire, and also of the specific historical context in which artistic influences might have been transmitted.

xix Jeremy Tanner, 'Figuring out death: sculpture and agency at the Mausoleum of Halicarnassus and the tomb of the First Emperor of China', in Liana Chua and Mark Elliott eds. Distributed Objects: Meaning and Mattering after Alfred Gell, Oxford, 2013, 58-87.

${ }^{x x}$ Nickel 'First Emperor', 414, 427 rightly emphasises not only the intrusive character of key features (naturalism emphasizing bone and muscle structure, monumentality), but 
also their immediate disappearance from the subsequent Chinese tradition before the arrival of Buddhism some four centuries later as telling evidence in favour of his account. On the Han terracotta armies: Ann Paludan, Chinese Sculpture: a Great Tradition, Chicago, 2006, 76-83; Wu Hung, 'From the Neolithic to the Han', in Angela Falco Howard, Li Song, Wu Hung and Yang Hong eds. Chinese Sculpture, New Haven, 2006, 76-9.

xxi J.-P. Reding, Comparative Essays in Early Greek and Early Chinese Rational Thinking, Aldershot, 2004, esp. p. 4 on norm-defect structures in comparative analysis. xxii Compare Haun Saussy, 'No time like the present: the category of contemporaneity in Chinese studies', in S. Shankman, and S.W. Durrant, eds. Early Greece/Ancient China. New York, 2002, 47, discussing comparative philosophy.

xxiii For a sociological account of art as an institution, based on the work of Michael Baxandall, see Jeremy Tanner 'Michael Baxandall and the sociological interpretation of art', Cultural Sociology 4.2, 2010, 231-56. For a similar, institutional, approach to postSong Chinese art, Richard Vinograd, 'Situation and response in traditional Chinese scholar painting', Journal of Aesthetics and Art Criticism 46.3, 1988, 365-74.

${ }^{x x i v}$ Gisela Richter, Greek Portraits: a Study of their Development, Collection Latomus 20, Bruxelles, 1955, 12 associating the origins of Greek portraiture with the development of 'the concept of and respect for the individual, an essential ingredient of our way of life'; Dieter Metzler, Porträt und Gesellschaft: über die Entstehung des griechischen Porträts in der Klassik, Munster, 1971, 62 for the link with Winckelmann.

${ }^{x x v}$ Dietrich Seckel, 'Das Porträt in Ostasien', in Martin Krantz (ed.) Das Bildnis in der Kunst des Orients. Stuttgart, 1990, 194.

xxvi John Boardman, Greek Sculpture: the Classical Period, London, 1985, 206; with Jeremy Tanner, The Invention of Art History in Ancient Greece: Religion, Society and Artistic Rationalisation, Cambridge, 2006, 98-103 for discussion of this kind of approach to Greek portraiture.

xxvii Dietrich Seckel, 'The rise of portraiture in Chinese art', Artibus Asiae 53, 1993, 12. xxviii Ernst Gombrich, Art and Illusion: a Study in the Psychology of Pictorial Representation, London, 1960, 78.

xxix Richard Brilliant, 'On portraits', Zeitschrift für Asthetik und allgemeine Kunstwissenschaft 16, 1971, 18. 
${ }^{\mathrm{xxx}}$ Dermys and Kittylos: Andrew Stewart, Greek Sculpture: an Exploration. New Haven, 1990, fig. 61. Klaus Fittschen, 'Griechische Porträts: zum Stand der Forschung', in Fittschen ed. Griechische Portrats, Darmstadt, 1988, 15-17 on archaic Greek statues of specific individuals. Late Warring States and Han funerary banners with representations of specific persons, the most notable that of Lady Dai from Mawangdui: Seckel, 'Rise of portraiture' 11-12; Wu Hung, 'The art and architecture of the Warring States period', in M. Loewe and E. Shaughnessey eds. The Cambridge History of Ancient China, from the Origins of Civilization to 221 BC, London, 1999, 743 on the third century BC Chu silk paintings from Chanjia and Zidanku as portraits; Zheng Yan, 'Mu zhu huaxiang yanjiu', 墓主畫像研究, Shandong daxue kaoguxi ed. Liu Dunyuan xiansheng jinian wenji 劉敦 原先生紀念文集,Ji'nan 濟南, 1998, 450. The development of honorific portraiture as a political institution, and of portraiture as an artistic genre, involved a radical transformation of the functions performed by these proto-portraits in their original funerary contexts. On the functions of Chinese funerary banners, especially from Mawangdui, see Wu Hung, The Art of the Yellow Springs: Understanding Chinese Tombs, London, 126-131. On the functions of early Greek funerary statuary: Jean-Pierre Vernant, 1983, 'The representation of the invisible and the psychological category of the double: the colossos', in Myth and Thought Among the Greeks, London, 305-320.

${ }^{x x x i}$ My synthetic approach, integrating analysis of cultural representation, social interaction and socio-political structures is based on Talcott Parsons' account of art as expressive symbolism. Reward symbolism is one category of expressive symbolism. See Jeremy Tanner, 'The body, expressive culture and social interaction: integrating art history and action theory' in Victor Lidz ed. Talcott Parsons. International Library of Essays in Classical Sociology, London, 2011, 523-562.

${ }^{\text {xxxii }}$ My account in this section builds on those of Tanner, Invention, 97-140, and G.J. Oliver, 'Space and the visualization of power in the Greek polis: the award of portrait statues in decrees from Athens', in Peter Schultz and Ralf von den Hoff eds. Early Hellenistic Portraiture: Image, Style and Context, Cambridge, 2007, 181-204. See Metzler, Porträt und Gesellschaft, 153-68 for the development of the concept of eikon. xxxiii Theophrastus, Characters ii.12.

${ }^{\text {xxxiv }}$ R.R.R. Smith, 'Pindar, athletes and the early Greek statue habit', in Simon Hornblower and Catherine Morgan eds. Pindar's Poetry, Patrons and Festivals, Oxford, 2007, 83-139 
xxxv Tanner Invention, 109-15; Oliver 'Space', 183-90.

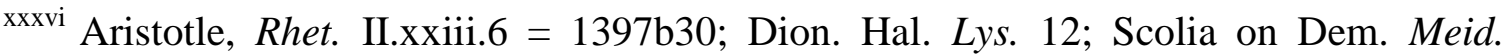
xxi.524.21.

xxxvii Lykourgos 14, frs. 1-4.

xxxviii Diod. Sic. xv.32-3; Corn. Nep. Chabrias I.2.

${ }^{\text {xxxix }}$ Plut. Alc. 16.5 .

${ }^{\mathrm{xl}}$ Xen. Mem. III.x.5.

xli Tanner, Invention, 124. N.B. Crowther, 'Male beauty contests in Greece: the euandria and the euexia', L'Antiquité Classique 54, 1985, 285-91; Crowther 'Euexia, eutaxia, philoponia: three contests of the Greek gymnasium', ZPE 85, 1991, 301-4. N.B. Reed, 'The euandria competition at the Panathenaia reconsidered", Ancient World 15, 1987, 5974.

xlii B. Fehr, Bewegungsweisen und Verhaltensideale: physiognomische Deutungsmöglichkeiten der Bewegungsdarstellungen an griechischen Statuen des 5 und 4 Jhs. V. Chr. Bad Bremstedt, 1979, 20-2. Tanner (2006), Invention, 121 discussing Plato Politicus 307a-b; Leg. 653e, 815e.f; Horoi 412d; Dem. xxxvii.52. Note also Jeremy Tanner, 'Social structure, cultural rationalisation and aesthetic judgement in classical Greece', in N. Keith Rutter and Brian A. Sparkes eds. Word and Image in Ancient Greece, Edinburgh, 2000, 198-203, esp. 200, n. 17, discussing Plato Laws VII.814e, on the quiet version of the good citizen at time of peace, versus the good citizen engaged in violent effort; Compare with Li Ji 30.21b-22a (Legge Rites II.25-6) for similar contextual and role specific sense of decorum for the official and the warrior, as discussed in Martin Powers, Art and Political Expression in Early China, New Haven, 1991, 64-5.

xliii Tanner, Invention, 126; quotations from Plato Laws 815a and Thuc. 1.70.

${ }^{\text {xliv }}$ Dem. xxxvii.55-6 with Joshua Ober, Mass and Elite in Democratic Athens: Rhetoric, Ideology and the Power of the People, Princeton, 1989, 151. Dem. xvl.77-8 with Ober, Mass and Elite, 221 and Tanner, Invention, 127.

${ }^{\mathrm{xlv}}$ Plut. Per. 5; Tanner, Invention, 128-9.

${ }^{x l v i}$ John K. Davies, Wealth and the Power of Wealth in Classical Athens. New York. 1981

xlvii Isok. i.15; Tanner, Invention, 131; Luca Giuliani, Bildnis und Botschaft: hermeneutische Untersuchungen zur Bildnis der römischen Republik, Frankfurt, 1986, 135. 
xlviii Tanner, Invention, 131; Aesch. In Ctesiph. iii.20 and Dem. xlv.68, liv.34 with Giuliani, Bildnis, 135.

xlix Tanner, Invention, 131, following Giuliani, Bildnis, 134-40 and Ralf von den Hoff, 1994, Philosophenporträts des früh- und hoch Hellenismus, Munich, 1994, 29-31 on brow contraction. Gisela, Portraits of the Greeks, volume II, 1965, 164-70, portrait of Plato.

${ }^{1}$ Paul Zanker, The Mask of Socrates: the Image of the Intellectual in Antiquity, Berkeley, 1995, 57-62.

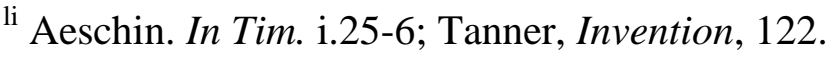

lii Dem. xix.251. The best discussion of this passage is that of Maria Catoni, 'Quale arte per il tempo di Platone', in S. Settis ed. I Greci, vol 2.ii: Una storia greca, ii, Definizione, Milan, 1997,1033-6.

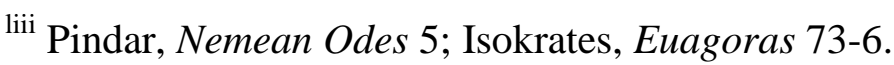

${ }^{\text {liv }}$ HS (Han Shu) 54.2468-9

${ }^{\text {lv }}$ HHS (Hou Han Shu) 60B.1998-9, quoting Yang Qiu's memorial of AD 178, protesting awards of honorific portraits for eunuchs in the Hongdu Academy.

${ }^{\text {lvi }}$ HHS 53.1748-51; Anthony J. Barbieri-Low, Artisans in Early Imperial China, Seattle, 2007, 207, and 305, note 165 .

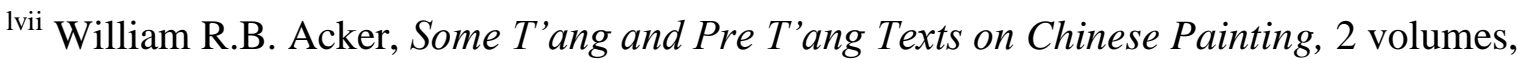
Leiden, 1954/1974, II.5. Barbieri-Low, Artisans, 55, with 269, note 44 on the probable authenticity of the story, as preserved in the Miscellaneous Notes of the Western Capital (Xijing zaji), the source quoted by Zhang Yanyuan.

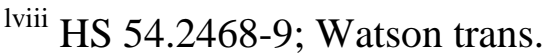

${ }^{\text {lix }}$ Wu Hung, The Wu Liang Shrine: the Ideology of Early Chinese Pictorial Art, Stanford, 1989, 192.

${ }^{1 x}$ Michael Nylan, 'Confucian piety and individualism in Han China", Journal of the American Oriental Society 116.1, 1996, 9, citing Tjan Tjoe Som Po Hu T'ung: The Comprehensive Discussions in the White Tiger Hall, (2 vols), Leiden, 1949-52, 521.

${ }^{1 x i}$ Lunheng 20.851, translated Alfred Forke, Lun-heng. Philosophical Essays of Wang Ch'ung, 2 vols, London, 1907, II.223; Barbieri-Low, Artisans, 158.

${ }^{1 x i i}$ HHS 22.788-91; Barbieri-Low, Artisans, 160.

${ }^{\text {1xiii } H H S ~ 22.788-91 ; ~ B a r b i e r i-L o w, ~ A r t i s a n s, ~ 160 ; ~ W u ~ H u n g, ~ W u ~ L i a n g ~ S h r i n e, ~} 192$ for the translation. 
${ }^{1 x i v}$ HHS 44.1510-13; Wu Hung Wu Liang Shrine, 193, with partial translation of the eulogy; Barbieri-Low, Artisans, 160.

${ }^{1 x v}$ HHS 77.2498-2499 with Barbieri-Low, Artisans, 166, Yang Qiu; Adriana G. Prosser, Moral Characters: Calligraphy and Bureaucracy in Han China 206 BCE - CE 220. Columbia PhD Thesis, New York, 1995, 73-4, citing Powers Art and Political Expression, 364: Cai Yong. Trans. Powers, modified. Precedents for portrait images of Confucius in an Academy may go back as far as the second century BC, when the administrator of the Shu (Sichuan) commandery, Wen Weng, established an academy for the education of local aspirants to office. Later (Song) traditions suggest there may have been engravings on stone of Confucius and his seventy two disciples, and in the third century AD, immediately after the Han, portraits of distinguished local officials may have been added to them. For discussion of the evidence: J. Michael Farmer, 'Art, education and power: illustrations in the stone chamber of Wen Weng', T'oung Pao lxxxvi: 100-135; Farmer, The Talent of Shu: Qiao Zhou and the Intellectual World of Early Medieval Sichuan, New York, 146-7. Such local initiatives in the creation of honorific portraits are less well attested than their central court counterparts, but may have been quite widespread. They may be compared with the extension of the practice of honorific portrait giving in Greek states, like Athens, downwards from the boule and demos to other corporate bodies, for example local demes, or groups of soldiers stationed in particular locales, as discussed in Oliver, 'Space and the visualisation of power'.

${ }^{\text {lxvi }}$ HHS 60B.1998-9; Michael Nylan, 'Calligraphy, the sacred text and the test of culture', in Cary C. Liu, Dora C. Y. Ching and Judith G. Smith, eds. Character and Context in Chinese Calligraphy, Princeton, 1999, 51. Barbieri-Low, Artisans, 178.

${ }^{1 x v i i}$ HHS 24.850-1.

${ }^{1 x v i i i}$ Susanne Greiff and Shenping Yin, Das Grab des Bin Wang: Wandmalereien der Ostlichen Han-Zeit in China, Wiesbaden, 2002. For the rereading of the inscriptions identifying the tomb as that of a General Guo, see Enno Giele, 'Das Wandmalereigrab in Dorf Baizi, Kreis Xunyi, Shanxi', in Michael Freidrich ed. Han Zeit. Festschrift für Hans Stumpfeldt aus Anlass seines 65 Geburtstages, Wiesbaden, 2006, 483-516; the issue is somewhat moot, since the final Chinese publication of the inscriptions has not yet appeared; Giele's case seems persuasive, but it does not make much difference either way for the purposes of my argument. 
1xix Jan Fontein and $\mathrm{Wu}$ Tung, Han and T'ang Mural Paintings Discovered in the People's Republic of China, Boston, 1976, 26-33. Hsin-mei Agnes Hsu, Pictorial Eulogies in Three Eastern Han Tombs, PhD Dissertation, University of Pennsylvania, 2004, chapter 2. Lydia DuPont Thompson, The Yi'nan Tomb: Narrative and Ritual in Pictorial Art of the Eastern Han (25-220 CE), PhD Dissertation, Institute of Fine Arts, New York University, 1998, 121-5 (discussing Wangdu Tomb). Beijing lishi bowuguan, 北京歷史博物館, Wangdu Hanmu Bihua, 望都漢墓壁畫, Beijing, 1955.

${ }^{1 x x}$ Hebei Sheng Wenwu Yanjiusuo, 河北省文物研究所, Anping Donghan Bihuamu. 安坪 東漢壁畫墓, Beijing,1990. Hsu, Pictorial Eulogies, chapter 3, 146-154 for the pictorial programme, 154 on attributes of the portrait of the deceased.

${ }^{1 x x i}$ Quoting Robert L. Thorp, and Richard E. Vinograd, Chinese Art and Culture, New York 2001, 144.

lxxii Jeehee Song, 'Path to the otherworld: funerary narrative rendered in Tokungri tomb murals', MA thesis, Department of Art History, University of Chicago, 2002. Wu Hung, The Art of the Yellow Springs: Understanding Chinese Tombs, London, 2010, 70-2 with good illustrations.

lxxiii J.K. Shryock, The Study of Human Abilities. The Jen wu chih of Liu Shao. New Haven, 1937. Anne-Marie Lara, Liu Shao: Traité des Caractères. Traduit du Chinois, présenté et annoté par Anne-Marie Lara, Paris, 1999.

${ }^{\text {lxxiv }}$ Licia D. Giacinto, 'The art of knowing others: the Renwu zhi and its cultural background', Oriens Extremus 43.1/2, 2002, 149.

${ }^{\text {lxxv }}$ Michael Loewe, 'The structure and practice of government', in Denis Twitchett and Michael Loewe eds. Cambridge History of China, volume 1: the Ch'in and Han Empires, 221 BC-AD 220, Cambridge, 1986, 463-6. Hans Bielenstein, 'The institutions of the Later Han', in Denis Twitchett and Michael Loewe eds. Cambridge History of China, volume 1: the Ch'in and Han Empires, 221 BC-AD 220, Cambridge, 1986, 515-7.

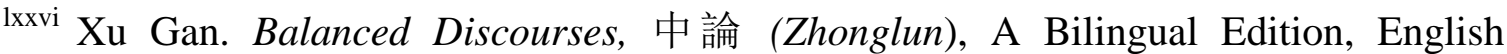
Translation by John Makeham, Introductions by Dang Shengyuan and John Makeham, New Haven, 2002.

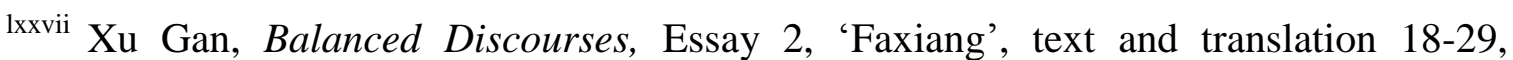
quotation p. 18-19. (Translation of Zhonglun throughout following Makeham with minor adjustments.) 
lxxviii Xu Gan, Balanced Discourses, 26-9.

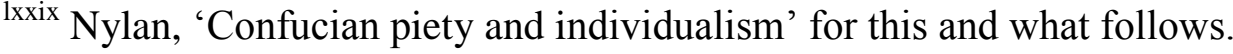

lxxx Nylan, 'Confucian piety and individualism', 9.

${ }^{1 \times x x i}$ Hsu, Pictorial Eulogies, $195 \mathrm{ff}$.

lxxxii Michael Nylan, 'On the politics of pleasure', Asia Major 14.1, 2001, 120, quoting Xunzi.

lxxiii Yantielun xxvii.3, translation based on Jean Levi ed., La Dispute sur le Sel et le Fer, 鹽鉄論, Texte présenté, traduit et annoté par Jean Levi, Paris, 2010, 148-9.

lxxiv Wang Chong, Lunheng 38, 'Bietong', Zhonghua Shuju ed. 596-7; trans. Forke, Lunheng, II,102. Compare Lunheng 60, 'Xusong'. Zhonghua Shuju ed. 851; trans. Forke, Lun-heng, II.223. 'A eulogy is much more than a simple picture... engraving encomiastic inscriptions regarding their illustrious virtue on bronze tripods'.

${ }^{\text {lxxxv }} \mathrm{Wu}$ Hung, 'Art and architecture of Warring States' 655. Lewis, Mark Edward, Sanctioned Violence in Early China, Albany, 1990, 5.

lxxxvi On the uses of kouroi and korai, discussing their distribution in Attica, and their links with a centrifugal construction of elite power, in tension with the centralising orientations of the tyrant Peisistratos, see: Richard Neer, The Emergence of the Classical Style in Greek Sculpture, Chicago, 2010, 21-30, esp. p. 30; Jonathan M. Hall, A History of the Archaic Greek World, Oxford, 2007, 222; Tanner Invention, 57-67.

lxxxvii $\mathrm{Wu}$ Hung, 'Art and architecture of Warring States', 651 and $675 \mathrm{ff}$ on rise of figurative art, and various forms of extremely lavish secular luxury art, in context of decline of ritual bronzes in Warring States period; 652 and 708ff: shifting focus from ancestral temples to tombs as primary symbols of elite status. Wu Hung, Monumentality in Early Chinese Art and Architecture, Stanford, 1996, 110-17.

lxxxviii Wu Hung, Monumentality, 88-121.

${ }^{\text {lxxxix }}$ On the long history of the process of state centralization in China, and the ongoing struggle against, local lineage-based fissive tendencies, see Mark Edward Lewis, The Construction of Space in Early China, New York, 2006, 136 - only in the third century $\mathrm{BC}$ that conquered cities cease to be handed over as personal fiefdoms to members of the nobility; 219: efforts to create new kinds of ties between individuals as the basis of political power and organisation, in place of the articulation of power - for example, the organisation of the military - through the kinship structures of the nobility. 


\section{TANNER PORTRAITS AND POLITICS - CAPTIONS}

Figure 1: Bernard Baron (1696-1762), after William Hogarth (1697-1764), Marriage à la Mode, Plate II, 1745. Etching and engraving, Platemark: 38 x $46.6 \mathrm{~cm}$. The Cleveland Museum of Art. Gift of Mr and Mrs Milton Curtiss Rose, 1759.312. Photo: Courtesy of the Cleveland Museum of Art.

Figure 2: John Zoffany (1733-1810). Charles Townley and his Friends in the Library of his House. 127 x 99 cm. Townley Hall Art Gallery, Burnley. Photo: Bridgeman Art Library.

Figure 3: The Tyrannicides, Harmodios and Aristogeiton. Roman marble copy of Greek bronze statues by Kritos and Nesiotes, 477/6 BC. Ht 1.85m. Museo Nazionale Naples. Photo: Soprintendeza per I Beni Archaeologici di Napoli.

Figure 4: Marble portrait head of Perikles, Roman copy after Greek bronze statue of late fifth century BC. Ht: 45cm. Pergamon Museum, Berlin. Photo: bpk / Antikensammlung, Staatliche Museen $\mathrm{Zu}$ Berlin.

Figure 5: Detail of Eastern Han funerary portrait, from Anping Tomb, Hebei Province. Late second century AD. Photo: after Hebei Sheng Wenwu Yanjiu Suo, Anping Dong Han Bihuamu. Wenwu Chubanshe. Plate 40. Reproduction Courtesy of Wenwu Chubanshe.

Figure 6: Funerary portrait from an Eastern Han tomb in Zhu Village. Early third century AD. After Huang Minglan and Guo Yinqiang eds. Luoyang Hanтu Bihua. Wenwu Chubanshe 1996, page 191. Reproduction courtesy of Wenwu Chubanshe.

Figure 7a: Roman marble portrait bust of a Strategos (Antikensammlung inv. Sk 311), copy after Greek bronze portrait statue of ca 390-370 BC, possibly Chabrias. Pergamon Museum, Berlin. Photo: bpk / Antikensammlung, Staatliche Museen Zu Berlin.

Figure 7b: Reconstruction of portrait of Chabrias, $4^{\text {th }}$ century BC. After J. Buckler, "A second look at the mounument of Chabrias", Hesperia 41, 1972, 466-74, plate 116. Reproduction courtesy of the American School of Classical Studies at Athens.

Figure 8: Roman bronze statuette, copy after Greek statue of late fourth or early fifth century BC. Wadsworth Atheneum, Hartford. Gift of J. Pierpoint Morgan. Ht. 27.94cm. Photo: Wadsworth Atheneum Museum of Art.

Figure 9: Attic funerary stele of Chairedemos and Lykeas from Salamis, late fifth century BC. Ht. 1.81m. Photo: Gösta Hellner, DAI Athen, Neg. D-DAI-ATH-Piräus 204 All rights reserved

Figure 10: Roman marble bust after Greek bronze portrait statue of Plato, fourth century BC. Ht. $35 \mathrm{~cm}$. Staatliche Antikensammlungen und Glypthothek München. Photography by Christa Koppermann.

Figure 11a: Marble statuette of Sokrates, Roman copy after Greek bronze statue of fourth century BC. Height: $27.5 \mathrm{~cm}$. Photo: British Museum. 
Figure 11b. Roman marble portrait head of Sokrates, after Greek bronze statue of fourth century BC. Louvre, Paris. Ht. 34cm. Photo: DeA Picture Library, licensed by Alinari.

Figure 12: Portrait of Sophokles, ca 330 BC. Roman marble copy after Greek bronze original. Ht: 2.04m. Vatican Museum. Photo: () Vatican Museums, All Rights Reserved.

Figure 13: Portrait of Aiskhines, ca 320 BC. Roman marble copy after Greek bronze original. 2.10m. Museo Nazionale Naples. Photo: Soprintendeza per I Beni Archaeologici di Napoli.

Figure 14a: Plan of Tomb of Bin Wang; Xunyi, Shaanxi Province, late $2^{\text {nd }}$ century AD. Photo: Römisch-Germanisches Zentralmuseum Mainz: J. Ribbeck after a concept of S. Greiff.

Figure 14b: General Guo and officials: wall painting rom the Tomb of Bin Wang. Photo: Römisch-Germanisches Zentralmuseum Mainz.

Figures 15 a) and b) Officials and Auspicious Animals, from Wangdu Tomb, Hebei, Late $2^{\text {nd }}$ century AD. Water colour copies of the original wall-paintings. Photo: after Wangdu Hanmu Bihua, plate 8 .

Figure 16a: Depiction of Officials, paying respect. Wall Painting. Anping Tomb, Sidechamber A. Anping Tomb, Hebei Province. Late second century AD. Photo: after Hebei Sheng Wenwu Yanjiu Suo, Anping Dong Han Bihuamu. Wenwu Chubanshe, pl. 45. Reproduction courtesy of Wenwu Chubanshe.

Figure 16b: Anping Tomb, Side Chamber B: Portrait of deceased from Anping Tomb, Hebei Province. Late second century AD. Photo: after Hebei Sheng Wenwu Yanjiu Suo, Anping Dong Han Bihuamu. Wenwu Chubanshe. Plate 40. Reproduction courtesy of Wenwu Chubanshe. 